\title{
Photo-Fenton Remediation of Wastewaters Containing Agrochemicals
}

\author{
Antonio Carlos Silva Costa Teixeira, Lucas Mendes, Giselle Stollar, Roberto Guardani and \\ Cláudio Augusto Oller do Nascimento* \\ Departamento de Engenharia Química; Escola Politécnica da Universidade de São Paulo; Av. Prof. Luciano \\ Gualberto, travessa 3, 380; 05508-900; oller@usp.br; São Paulo - SP - Brasil
}

\begin{abstract}
The photochemical degradation of agrochemicals in aqueous solution by means of advanced oxidation processes (AOPs) was studied. The photo-Fenton process was evaluated in terms of the time evolution of dissolved organic carbon (COD) and chemical oxygen demand (DOC), their total removals, and increase in biodegradability of treated wastewater. Under the experimental conditions studied, the process showed to be superior to other AOPs, at any $\mathrm{Fe}(\mathrm{II})$ and $\mathrm{H}_{2} \mathrm{O}_{2}$ concentrations. The results pointed towards the use of solar irradiation and low cost commercial application.
\end{abstract}

Key words: Advanced Oxidation Processes, photo-Fenton, agrochemicals, wastewater

\section{INTRODUCTION}

The problem of adequate fresh water resources can be expected to worsen as a result of population growth, industrial and agricultural demands, with large impacts on the hydrological cycle, aquatic ecosystems, and subterranean and surface water sources (Tundisi, 2003). Liquid effluents containing toxic substances are generated by a wide variety of chemical processes, as well as by a number of other common household and agricultural applications. In this context, pesticides and other agrochemicals are toxic recalcitrant compounds, which may accumulate in the environment. They can be present in wastewater from industrial processes and farm works operations (rinse water from spray equipment and empty pesticide containers, washing and postharvest treatment of fruits and vegetables etc.) (Malato et al., 2000). The inadequate management of these effluents can have harmful consequences to human health.

The known technical and economical drawbacks of conventional treatments (flocculation, filtration, precipitation, adsorption onto active charcoal, etc.) and biological processes (activated sludge) (Esplugas et al., 2002) have fueled the development of new, more effective and economically viable methods for pollution prevention. In this context, the Advanced Oxidation Processes (AOPs) have enormous potential for becoming viable alternatives for the remediation of polluted wastewater (Chiron et al., 1999; Teixeira et al., 2003; Teixeira et al. 2004). Oxidation of organic pollutants implies in most cases the generation and subsequent reactions of hydroxyl radicals $\left(\mathrm{HO}^{\bullet}\right)$. These are short-lived, powerful oxidizing agents, which react by second order kinetics with the majority of organic

\footnotetext{
* Author for correspondence
} 
substances with low selectivity and at rates often approaching the diffusion-controlled limit (rate constants in the range $10^{11}-10^{13} \mathrm{mmol} \mathrm{L}^{-1} \mathrm{~s}^{-1}$, and $\left[\mathrm{HO}^{\bullet}\right]=10^{-7}-10^{-9} \mathrm{mmol} \mathrm{L}{ }^{-1}$, Esplugas et al., 2002). Hydroxyl radical are produced in situ by chemical and/or photochemical reactions in AOP systems (oxidant \{catalyst (when present)\}/light). The following AOPs appear to be particularly promising for practical industrial applications:

(a) $\mathrm{H}_{2} \mathrm{O}_{2} / \mathrm{UV}$ : direct photolysis of $\mathrm{H}_{2} \mathrm{O}_{2}$ molecules in aqueous solutions by UV radiation of wavelength shorter than $300 \mathrm{~nm}$ :

$$
\mathrm{H}_{2} \mathrm{O}_{2} \stackrel{h v}{\longrightarrow} 2 \mathrm{HO}^{\bullet}
$$

The AOP based on $\mathrm{H}_{2} \mathrm{O}_{2} / \mathrm{UV}$ has been used in the treatment of pesticide-contaminated waters (Burrows et al., 2002).

(b) $\left\{\mathrm{TiO}_{2}\right\} / \mathrm{UV}$ : The heterogeneous photocatalysis is based on the activation of $\mathrm{TiO}_{2}$ by UV-light of wavelength shorter than $387 \mathrm{~nm}$. Electrons $\left(e^{-}\right)$are excited from the conduction band into the valence band, with the generation of positive holes $\left(h^{+}\right)$in the valence band. Organic molecules (RH) and $\mathrm{H}_{2} \mathrm{O}$, adsorbed on the catalyst surface, are oxidized by the holes, leading to the formation of cationic $\left(\mathrm{R}^{+\bullet}\right)$ and $\mathrm{HO}^{\bullet}$ radicals, respectively, which may oxidize RH molecules:

$$
\begin{aligned}
& h^{+}-\mathrm{Ti}(\mathrm{IV})-\mathrm{OH}_{2} \longrightarrow \mathrm{Ti}(\mathrm{IV})-\mathrm{HO}^{\bullet}+\mathrm{H}^{+} \\
& h^{+}-\mathrm{Ti}(\mathrm{IV})-\mathrm{RH} \longrightarrow \mathrm{Ti}(\mathrm{IV})-\mathrm{R}^{+\bullet}
\end{aligned}
$$

The photodegradation of pesticides using $\mathrm{TiO}_{2} / \mathrm{UV}$ is described by Malato et al. (2000).

(c) $\mathrm{H}_{2} \mathrm{O}_{2}-\mathrm{Fe}(\mathrm{II})$ (Fenton reaction) and $\mathrm{H}_{2} \mathrm{O}_{2}$ $\{\mathrm{Fe}(\mathrm{II}) / \mathrm{Fe}(\mathrm{III})\} / \mathrm{UV}$-visible $\quad$ (photo-Fenton): thermal redox reactions between $\mathrm{Fe}(\mathrm{II}) / \mathrm{Fe}$ (III) and $\mathrm{H}_{2} \mathrm{O}_{2}$ (Chiron et al., 1999; Esplugas et al., 2002):

$$
\begin{aligned}
& \mathrm{Fe}^{2+}+\mathrm{H}_{2} \mathrm{O}_{2} \longrightarrow \mathrm{Fe}^{3+}+\mathrm{HO}^{\bullet}+\mathrm{OH}^{-} \\
& \mathrm{Fe}^{3+}+\mathrm{H}_{2} \mathrm{O}_{2}+\mathrm{H}_{2} \mathrm{O} \longrightarrow \mathrm{Fe}^{2+}+\mathrm{H}_{3} \mathrm{O}^{+}+\mathrm{HO}_{2}^{-}
\end{aligned}
$$

Under UV-visible irradiation, the following photochemical reaction occurs:

$$
\mathrm{Fe}(\mathrm{OH})^{2+} \stackrel{h v}{\longrightarrow} \mathrm{Fe}^{2+}+\mathrm{HO}^{\bullet}
$$

Reaction 6 enhances the reduction of Fe(III) species. The optimum $\mathrm{pH}$ for this reaction is about 3.0 (Lipczynska-Kochany, 1991). The main primary photoactive species at this $\mathrm{pH}$, $[\mathrm{Fe}(\mathrm{OH})]_{\mathrm{aq}}^{2+}$ (Bossmann et al., 1998), absorbs light in the range $290-410 \mathrm{~nm}$ of the spectrum.

The use of the Fenton and photo-Fenton processes in the treatment of pesticide-containing wastewater is a recent matter. The degradation of triazine herbicides (Burrows et al., 2002), methylparathion (Chiron et al., 1999), fenuron (Acero et al., 2002) and diuron (Burrows et al., 2002) are known examples.

In this work, the efficiency of AOPs in the remediation of wastewater contaminated with the active compounds of a fungicide (tebuconazole) and an insecticide/acaricide (methamidophos), largely employed in crops in the State of São Paulo, Brazil, was investigated at the bench-scale level. The effects of $\mathrm{Fe}$ (II) and $\mathrm{H}_{2} \mathrm{O}_{2}$ concentrations, temperature, radiation, and pollutant were investigated in the case of the photo-Fenton process.

\section{MATERIALS AND METHODS}

A schematic view of the experimental setup used in this work is shown in Fig. 1. All experiments were carried out in the same equipment. The equipment consisted of an annular photochemical reactor (Ace Glass, model 7863-20) with a net volume of $0.5 \mathrm{~L}$, connected to a $1-\mathrm{L}$ jacketed glass reservoir. A 450-W medium pressure mercury lamp (Ace-Hanovia, model 7825-34), placed inside a quartz-well, was used as the light source. The liquid in the tank was well mixed, and its temperature was controlled by means of a thermoregulated bath. A centrifugal pump provided liquid circulation $\left(0.025 \mathrm{~L} \mathrm{~s}^{-1}\right)$ for reactor operation in the recirculating batch mode.

The experimental procedure was the same in all runs. First, the pollutant aqueous solution $(2 \mathrm{~L})$ was introduced into the reactor. $\mathrm{pH}$ was adjusted at 3.0 by the addition of $\mathrm{H}_{2} \mathrm{SO}_{4}$, and then continuously monitored. Reactants were added, and the light source was turned on in irradiated systems. 


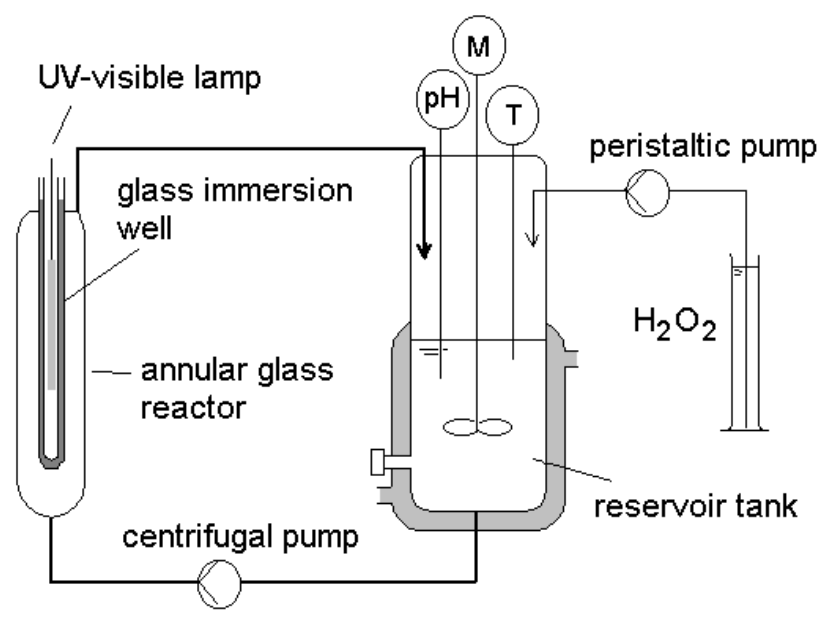

Figure 1 - Schematic view of the experimental setup. M, rotating impeller connected to an agitator device. $\mathrm{T}$, temperature sensor connected to a digital indicator. $\mathrm{pH}$, electrode connected to a digital $\mathrm{pH}$ meter.

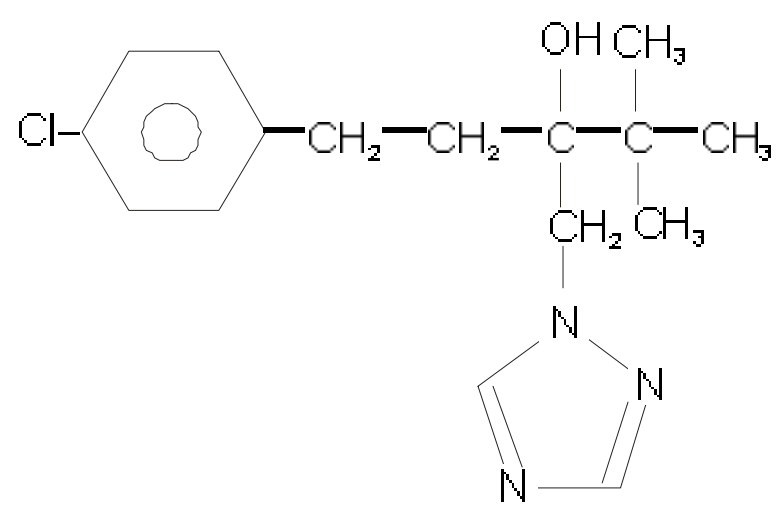

Figure 2 - Molecular structure of tebuconazole.

Weighed amount of solid $\mathrm{FeSO}_{4} \cdot 7 \mathrm{H}_{2} \mathrm{O}(>98 \%$, Sigma Aldrich) was added in the beginning. A peristaltic pump (Ismatec-IPC) was used to feed $\mathrm{H}_{2} \mathrm{O}_{2}$ solution throughout the irradiation time (180 minutes) at a controlled flow rate $\left(6.67 \mu \mathrm{L} \mathrm{s}^{-1}\right)$. Hydrogen peroxide solutions were prepared using a $\mathrm{H}_{2} \mathrm{O}_{2}$ analytical grade stock-solution $(30 \% \mathrm{w} / \mathrm{w}$ in water, Merck). All solutions were prepared with distilled water. In the experiment using $\mathrm{TiO}_{2}(\mathrm{P} 25$, Degussa), the photocatalyst concentration was 500 $\mathrm{mg} \mathrm{L}^{-1}$.

Ten-milliliter samples were taken from the reservoir at specified times for the characterization of pollutant degradation. The chemical oxygen demand (COD) of each sample was measured by the closed-reflux colorimetric method according to standard techniques (Standard Methods for the Examination of Water and Wastewater, procedure 5220). The concentration of dissolved organic carbon (DOC) was measured using the Shimadzu 5000A equipment. In some cases, the biochemical oxygen demand $\left(\mathrm{BOD}_{5}\right)$ of the final treated solution was measured by the respirometric method using the Oxitop IS 12 manometric respirometer (WTW), according to standard procedures (Standard Methods for the Examination of Water and Wastewater, procedure 5210). The analyses were performed immediately after samples had been collected.

In Fenton, photo-Fenton, and $\mathrm{H}_{2} \mathrm{O}_{2} / \mathrm{UV}$ experiments a solution containing $\mathrm{KI}, \mathrm{Na}_{2} \mathrm{SO}_{3}$ and $\mathrm{NAOH}$ (each $0.1 \mathrm{~mol} \mathrm{~L}^{-1}$ ) was added to the 
samples for the DOC analysis in the proportion 5:2 $\mathrm{v} / \mathrm{v}$ (sample:solution). This quenching solution allowed the decomposition of residual $\mathrm{H}_{2} \mathrm{O}_{2}$ and the precipitation of $\mathrm{Fe}(\mathrm{II}) / \mathrm{Fe}$ (III) ions. All samples were then filtered through a $0.22-\mu \mathrm{m}$ membrane.

The aqueous solutions containing the pollutants were prepared from commercial agrochemical formulations. In the case of the fungicide tebuconazole ( $\alpha$-terc-butyl- $\alpha$-(p-chlorophenylethyl)-1H-1,2,4,-triazole-1-ethanol, Fig. 2), an aqueous suspension $\left(1000 \mathrm{mg} \mathrm{L}^{-1}\right)$ of Folicur ${ }^{\circledR} \mathrm{PM}$ (Bayer CropScience, wettable powder, 25\% w/w in active compound) was vigorously stirred for $2 \mathrm{~h}$ and then filtered through $2 \mu \mathrm{m}$ pore size filters.

The filtrate containing tebuconazole and inert compounds had $\mathrm{COD}_{0}=216 \pm 27 \mathrm{mg} \mathrm{L}^{-1}$; $\mathrm{DOC}_{0}=66 \pm 9 \mathrm{mg} \mathrm{L}^{-1} ; \mathrm{BOD}_{5}=5 \mathrm{mg} \mathrm{L}^{-1}$; and $\mathrm{pH}=8.5$. The conditions of the experiments carried out with Folicur ${ }^{\circledR} \mathrm{PM}$ are listed in Table 1.

In the case of the insecticide/acaricide methamidophos (O,S-dimethylphosphoramidothiolate, Fig. 3), an aqueous solution containing $1 \mathrm{~mL} \mathrm{~L}^{-1}$ of the formulation Tamaron ${ }^{\circledR}$ BR (Bayer CropScience, concentrated liquid emulsion, $60 \% \mathrm{v} / \mathrm{w}$ in active compound) was used. The solution (methamidophos and inert compounds) had $\mathrm{COD}_{0}=864 \pm 12 \mathrm{mg} \mathrm{L}^{-1}$; $\mathrm{DOC}_{0}=245 \pm 8 \mathrm{mg} \mathrm{L}{ }^{-1} ; \mathrm{BOD}_{5}=5 \mathrm{mg} \mathrm{L}^{-1}$; and $\mathrm{pH}=4.5$. Table 2 presents the conditions of the experiments carried out with Tamaron $^{\circledR}$ BR solutions.

Table 1 - Conditions of the experiments carried out with Folicur ${ }^{\circledR} \mathrm{PM}$

\begin{tabular}{|c|c|c|}
\hline Experiment (a) & {$\left[\mathrm{H}_{2} \mathrm{O}_{2}\right]\left(\mathrm{mmol} \mathrm{L}^{-1}\right)(\mathrm{b})$} & {$[\mathrm{Fe}(\mathrm{II})]\left(\mathrm{mmol} \mathrm{L}^{-1}\right)(\mathrm{c})$} \\
\hline $\begin{array}{l}\text { A: } \mathrm{H}_{2} \mathrm{O}_{2} ; 30^{\circ} \mathrm{C} \\
\text { UV }\end{array}$ & 500 & - \\
\hline $\begin{array}{l}\text { B: } \mathrm{TiO}_{2}\left(500 \mathrm{mg} \mathrm{L}^{-1}\right) \\
\quad \mathrm{UV} ; 30^{\circ} \mathrm{C}\end{array}$ & - & - \\
\hline $\begin{array}{l}\text { C: } \mathrm{Fe}(\mathrm{II})+\mathrm{H}_{2} \mathrm{O}_{2} ; 30^{\circ} \mathrm{C} \\
\quad \text { non-irradiated (dark) }\end{array}$ & 500 & 0.5 \\
\hline $\begin{array}{l}\text { D: } \mathrm{Fe}(\mathrm{II})+\mathrm{H}_{2} \mathrm{O}_{2} ; 30^{\circ} \mathrm{C} \\
\quad \text { UV-visible }\end{array}$ & 50 & 2.8 \\
\hline $\begin{array}{l}\text { E: } \mathrm{Fe}(\mathrm{II})+\mathrm{H}_{2} \mathrm{O}_{2} ; 30^{\circ} \mathrm{C} \\
\quad \text { UV-visible }\end{array}$ & 50 & 0.5 \\
\hline $\begin{array}{l}\text { F: } \mathrm{Fe}(\mathrm{II})+\mathrm{H}_{2} \mathrm{O}_{2} ; 30^{\circ} \mathrm{C} \\
\quad \text { UV-visible }\end{array}$ & 500 & 0.5 \\
\hline $\begin{array}{l}\text { G: } \mathrm{Fe}(\mathrm{II})+\mathrm{H}_{2} \mathrm{O}_{2} ; 50^{\circ} \mathrm{C} \\
\quad \text { UV-visible }\end{array}$ & 50 & 0.5 \\
\hline $\begin{array}{l}\text { H: } \mathrm{Fe}(\mathrm{III})+\mathrm{H}_{2} \mathrm{O}_{2} ; 30^{\circ} \mathrm{C} \\
\quad \text { UV-visible }\end{array}$ & 10 & 0.55 \\
\hline $\begin{array}{l}\text { I: } \mathrm{Fe}(\mathrm{II})+\mathrm{H}_{2} \mathrm{O}_{2} ; 30^{\circ} \mathrm{C} \\
\quad \text { UV-visible }\end{array}$ & 100 & 0.55 \\
\hline
\end{tabular}

(a) $\mathrm{pH}$ previously adjusted at 3.0 in all experiments; (b) $\mathrm{H}_{2} \mathrm{O}_{2}$ concentration of the feed solution; (c) initial Fe(II) concentration of the aqueous solutions; $\mathrm{Fe}(\mathrm{II})+\mathrm{H}_{2} \mathrm{O}_{2}$, dark Fenton reaction; $\mathrm{Fe}(\mathrm{II})+\mathrm{H}_{2} \mathrm{O}_{2}+\mathrm{UV}$-visible, photo-Fenton reaction. 


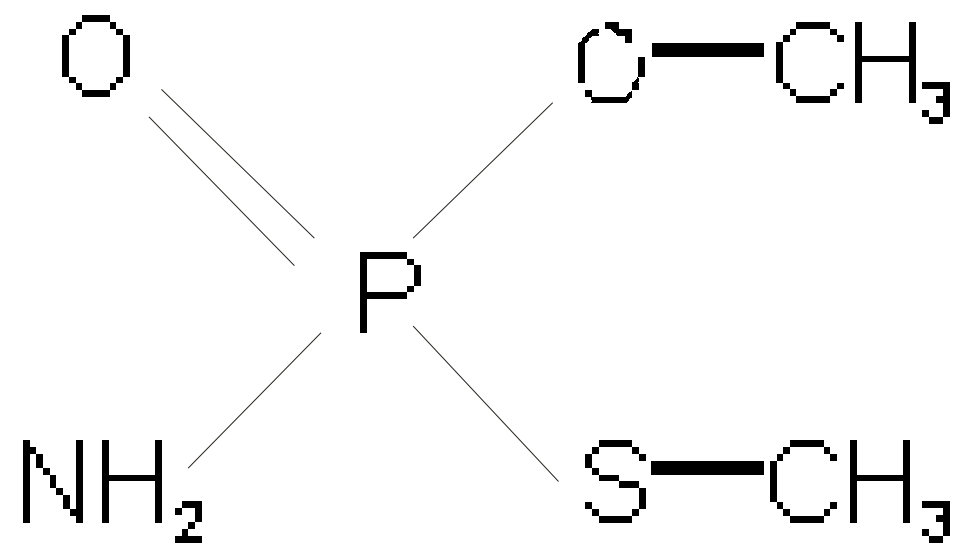

Figure 3 - Molecular structure of methamidophos.

Table 2 - Conditions of the experiments carried out with Tamaron ${ }^{\circledR}$ BR

\begin{tabular}{|c|c|c|}
\hline $\begin{array}{c}\text { Experiment } \\
\text { (a) }\end{array}$ & {$\left[\mathrm{H}_{2} \mathrm{O}_{2}\right]\left(\mathrm{mmol} \mathrm{L}^{-1}\right)(\mathrm{b})$} & {$[\mathrm{Fe}(\mathrm{II})]\left(\mathrm{mmol} \mathrm{L}^{-1}\right)(\mathrm{c})$} \\
\hline $\begin{array}{l}\text { J: } \mathrm{Fe}(\mathrm{II})+\mathrm{H}_{2} \mathrm{O}_{2} ; 30^{\circ} \mathrm{C} \\
\text { UV-visible }\end{array}$ & 55 & 0.55 \\
\hline $\begin{array}{l}\mathbf{K}: \mathrm{Fe}(\mathrm{II})+\mathrm{H}_{2} \mathrm{O}_{2} ; 30^{\circ} \mathrm{C} \\
\text { UV-visible }\end{array}$ & 550 & 0.55 \\
\hline
\end{tabular}

(a) $\mathrm{pH}$ previously adjusted at 3.0 in all experiments; (b) $\mathrm{H}_{2} \mathrm{O}_{2}$ concentration of the feed solution; (c) initial Fe(II) concentration of the aqueous solutions; $\mathrm{Fe}(\mathrm{II})+\mathrm{H}_{2} \mathrm{O}_{2}+\mathrm{UV}$-visible, photo-Fenton reaction.

\section{RESULTS AND DISCUSSION}

Fig. 4 presents the time evolution of COD (chemical oxygen demand), DOC (dissolved organic carbon), and $\mathrm{pH}$ for experiments $\mathbf{A}$ $\left(\mathrm{H}_{2} \mathrm{O}_{2} / \mathrm{UV}\right), \mathbf{B}\left(\mathrm{TiO}_{2} / \mathrm{UV}\right), \mathbf{C}$ (dark Fenton), and $\mathbf{F}$ (photo-Fenton) carried out with Folicur $^{\circledR}$ PM. Under the conditions of these experiments (Table 1), the AOP based on the photo-Fenton reaction (Fig. 4, curve F) showed the best performance. In this case, a rapid removal of both DOC $(89 \%$ after 180 minutes) and COD (86\%) was achieved; after an hour, the photo-Fenton reaction enabled to reduce DOC and COD to 32 and 27\%, respectively, of their initial values. These results suggested the mineralization of the pollutants (tebuconazole and inert compounds) during the treatment process. The decrease in $\mathrm{pH}$ values was associated with the formation of organic acids as degradation products, which were degraded later or associated with the amount of non-mineralized organic carbon (approx. 11\%). The non-irradiated Fenton process (experiment $\mathbf{C}$, Table 1), carried out at the same temperature, $\left[\mathrm{H}_{2} \mathrm{O}_{2}\right]$, and $[\mathrm{Fe}(\mathrm{II})]$, resulted in the poorest performance. In the absence of light and after the consumption of all $\mathrm{Fe}$ (II) by reaction $4, \mathrm{H}_{2} \mathrm{O}_{2}$ accumulated in the system after approx. 30-45 minutes, with a noticeable interference in COD measurements (Fig. 4, curve $\mathrm{C}$ ), and a small variation in DOC values (only $11 \%$ total removal). The thermal reduction (reaction 5) was much slower than the initial step (reaction 4) and ultimately determined the overall rate at which the process proceeded. The generation of $\mathrm{HO}^{\bullet}$ radicals slowed down appreciably after the initial conversion of $\mathrm{Fe}(\mathrm{II})$ to $\mathrm{Fe}$ (III) and requires the addition of relatively large amounts of iron in order to degrade the pollutant. The photo-Fenton degradation (Fig. 4, curve F) was much faster than the thermal Fenton reaction. 

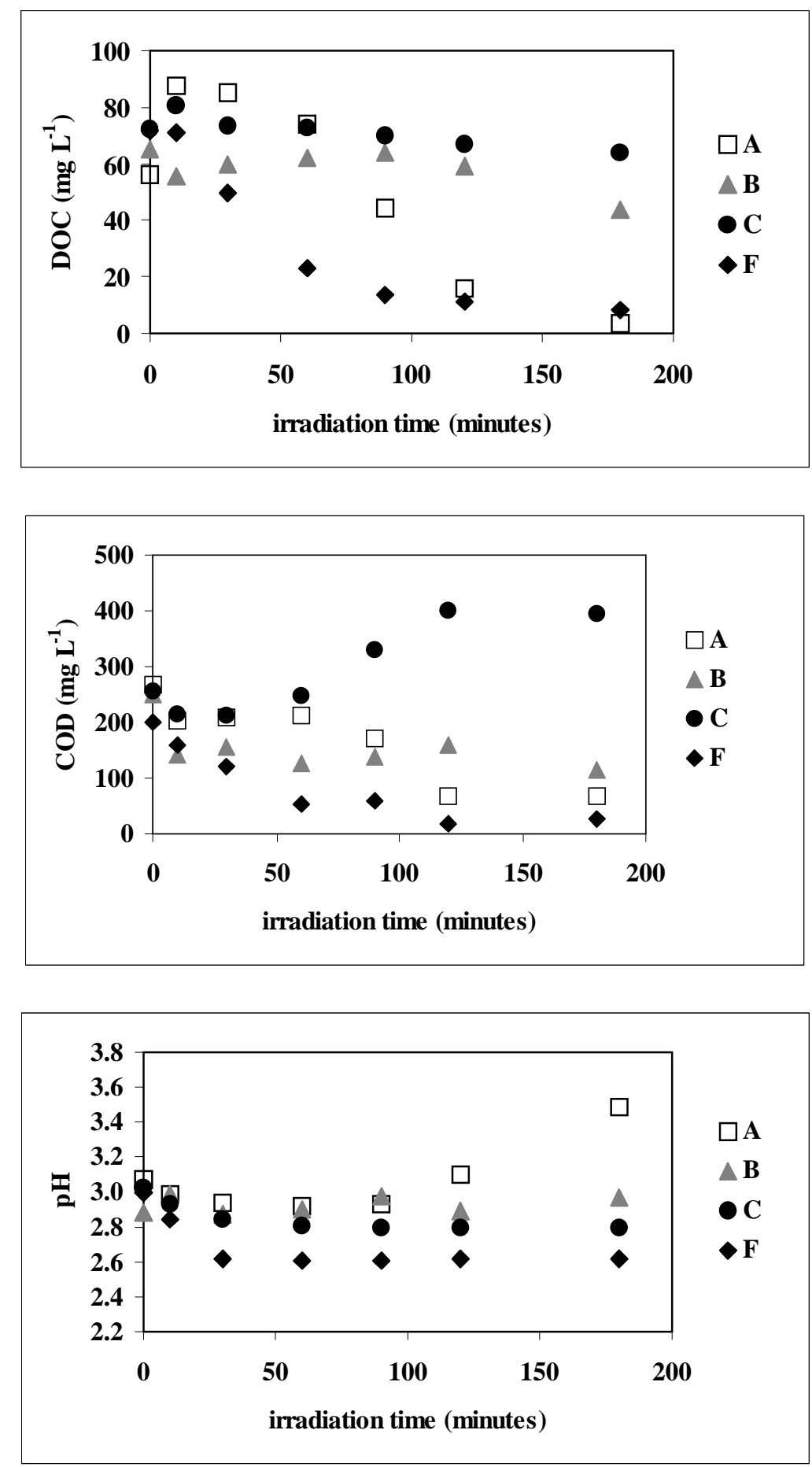

Figure 4 - Results of the experiments carried out with Folicur ${ }^{\circledast}$ PM. A $\left(\mathrm{H}_{2} \mathrm{O}_{2} / \mathrm{UV}\right.$; $\left.\left[\mathrm{H}_{2} \mathrm{O}_{2}\right]=500 \mathrm{mmol} \mathrm{L}^{-1} ; 30^{\circ} \mathrm{C}\right) ; \mathbf{B}\left(\mathrm{TiO}_{2} 500 \mathrm{mg} \mathrm{L}^{-1} / \mathrm{UV} ; 30^{\circ} \mathrm{C}\right) ; \mathbf{C}$ (Fenton;

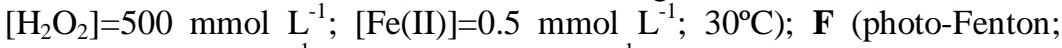
$\left.\left[\mathrm{H}_{2} \mathrm{O}_{2}\right]=500 \mathrm{mmol} \mathrm{L}^{-1} ;[\mathrm{Fe}(\mathrm{II})]=0.5 \mathrm{mmol} \mathrm{L}^{-1} ; 30^{\circ} \mathrm{C}\right)$.

Therefore, irradiation of the Fenton reaction not only regenerated $\mathrm{Fe}(\mathrm{II})$, the crucial catalytic species in the Fenton reaction (reaction 4), but also produced an additional $\mathrm{HO}^{\bullet}$ radical, the species responsible for chain reactions involved in the degradation of the pollutants. As a consequence of 
these two effects, the photo-Fenton process was much more rapid than the conventional thermal Fenton process. Moreover, since $\mathrm{Fe}(\mathrm{II})$ was regenerated by light with decomposition of water in the iron complex (reaction 6) rather than thermally via reduction by $\mathrm{H}_{2} \mathrm{O}_{2}$ (reaction 5), the photo-Fenton process consumed less $\mathrm{H}_{2} \mathrm{O}_{2}$ and required only catalytic amounts of $\mathrm{Fe}(\mathrm{II})$.

Pollutant degradation proceeded slowly in the case of the $\mathrm{TiO}_{2} / \mathrm{UV}$ process (Fig. 4, curve B), with a small variation in DOC values and approx. $40 \%$ removal of COD after 120 minutes; $\mathrm{pH}$ values remained virtually the same. In other words, the heterogeneous AOP enabled a slow degradation of the contaminant, although total mineralization was not achieved as suggested by the time evolution of DOC values, which did not undergo a substantial variation throughout the irradiation time. In this case, more recalcitrant degradation products should remain dissolved. Such products should be less prone to further oxidation when compared to those generated in the photo-Fenton process as suggested by the corresponding COD-time curves in each case (Fig. 4). It could be possible that the poor performance of the $\mathrm{TiO}_{2} / \mathrm{UV}$ process in comparison with homogeneous irradiated processes $\left(\mathrm{H}_{2} \mathrm{O}_{2} / \mathrm{UV}\right.$ and specially the photoFenton reaction) would be due to the concentration of photocatalyst used $\left(500 \mathrm{mg} \mathrm{L}^{-1}\right)$. The increased number of $\mathrm{TiO}_{2}$ particles in suspension, per unit volume of liquid, favored photo-activation and thus the generation of $\mathrm{HO}^{\bullet}$ radicals and/or the direct oxidation of adsorbed organic molecules. However, a limited depth of penetration of the incident radiation into the suspension, due to the strong scattering of light by the catalyst particles was also observed. To verify these possibilities, the $\mathrm{TiO}_{2} / \mathrm{UV}$ process was repeated at a lower catalyst concentration $\left(50 \mathrm{mg} \mathrm{L}^{-1}\right)$, resulting in a similar behavior in terms of COD and DOC-time curves. Recombination of $h^{+} / e^{-}$pairs and the reduction of hydroxyl radicals by electrons in the conduction band also contributed to lower the quantum yield of the heterogeneous process.

For $\mathrm{H}_{2} \mathrm{O}_{2} / \mathrm{UV}$ process, the initial increase in DOC values was probably due to experimental errors, and should not be considered. A slow decrease in DOC values, with more than $90 \%$ removal at the end of the irradiation time along with approx. $74 \%$ removal of $\mathrm{COD}$, were obtained; $\mathrm{pH}$ values initially underwent a small decrease, with a further increase after 90-100 minutes.
These results confirmed that the $\mathrm{H}_{2} \mathrm{O}_{2} / \mathrm{UV}$ process, although less efficient than the photo-Fenton reaction, also enabled pollutant degradation. However, $\mathrm{H}_{2} \mathrm{O}_{2}$ absorbed only weakly in the UV at wavelengths shorter that $300 \mathrm{~nm}$. This required the use of relatively high concentrations of $\mathrm{H}_{2} \mathrm{O}_{2}$ and precludes the application of this process to aqueous solutions of organic compounds that absorbed strongly in the UV below $300 \mathrm{~nm}$, as was the case of tebuconazole solutions. Furthermore, at these higher concentrations, $\mathrm{H}_{2} \mathrm{O}_{2}$ itself consumed $\mathrm{HO}^{\bullet}$, decreasing the degradation efficiency of the system.

Fig. 5 compares the photo-Fenton degradation carried out at two different temperatures at the same $\mathrm{H}_{2} \mathrm{O}_{2}$ and $\mathrm{Fe}(\mathrm{II})$ concentrations using Folicur ${ }^{\circledR}$ PM. (experiments $\mathbf{E}$ and $\mathbf{G}$, Table 1).

DOC-time curves were virtually the same at 30 and $50^{\circ} \mathrm{C}$, except the values obtained after 180 minutes of irradiation. On the other hand, as reaction 6 was less sensitive to temperature, the faster decrease in COD values at $50^{\circ} \mathrm{C}$ should be due to the increased rate of oxidative chain reactions involving the degradation products of tebuconazole and inert compounds. Considering the same irradiation time, in experiment $\mathbf{G}$, the concentration of organic compounds that could be oxidized at any time was smaller and the carbon balance was rather equivalent. This suggested different reaction pathways for each temperature.

Fig. 6 compares the results obtained for the photoFenton experiments carried out with Folicur ${ }^{\circledR}$ PM, at different $\mathrm{Fe}(\mathrm{II})$ and $\mathrm{H}_{2} \mathrm{O}_{2}$ concentrations, and the same temperature (Table 1). The analysis of DOC and COD-time curves revealed that a tenfold increase in $\left[\mathrm{H}_{2} \mathrm{O}_{2}\right]$ led to an increased rate of pollutant degradation, and to increased total DOC and COD percent removals, for both $\mathrm{Fe}(\mathrm{II})$ concentrations examined (Fig. 6, curves E and F; $\mathrm{H}$ and $\mathrm{I})$. 

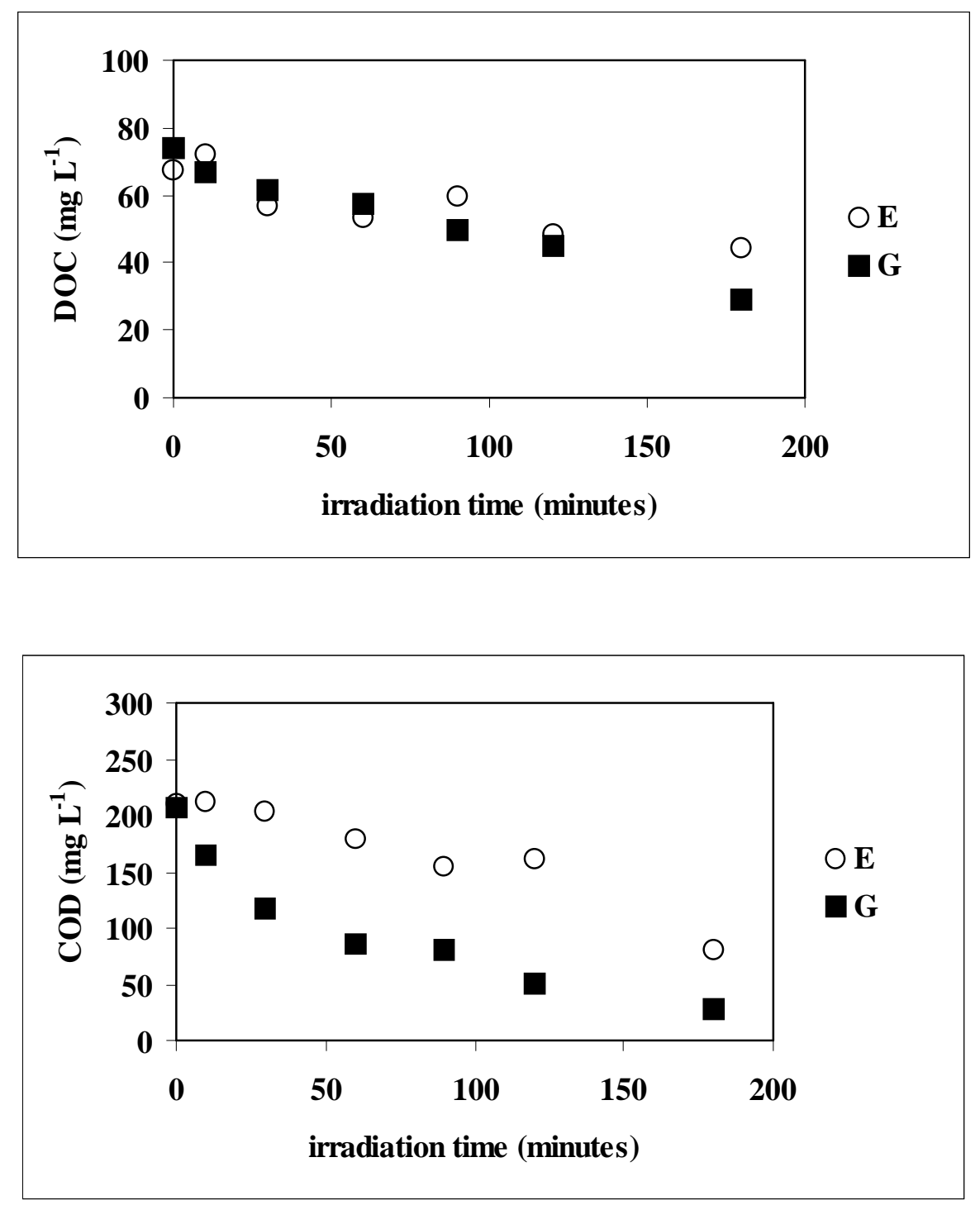

Figure 5 - Results of the photo-Fenton experiments carried out with Folicur ${ }^{\circledR}$ $\mathrm{PM}$, at different temperatures. $\mathbf{E}\left(\left[\mathrm{H}_{2} \mathrm{O}_{2}\right]=50 \mathrm{mmol} \mathrm{L}^{-1}\right.$; $[\mathrm{Fe}(\mathrm{II})]=0.5$ $\left.\mathrm{mmol} \mathrm{L}{ }^{-1} ; 30^{\circ} \mathrm{C}\right) ; \mathbf{G}\left(\left[\mathrm{H}_{2} \mathrm{O}_{2}\right]=50 \mathrm{mmol} \mathrm{L}^{-1} ;[\mathrm{Fe}(\mathrm{II})]=0.5 \mathrm{mmol} \mathrm{L}^{-1}\right.$; $\left.50^{\circ} \mathrm{C}\right)$. 

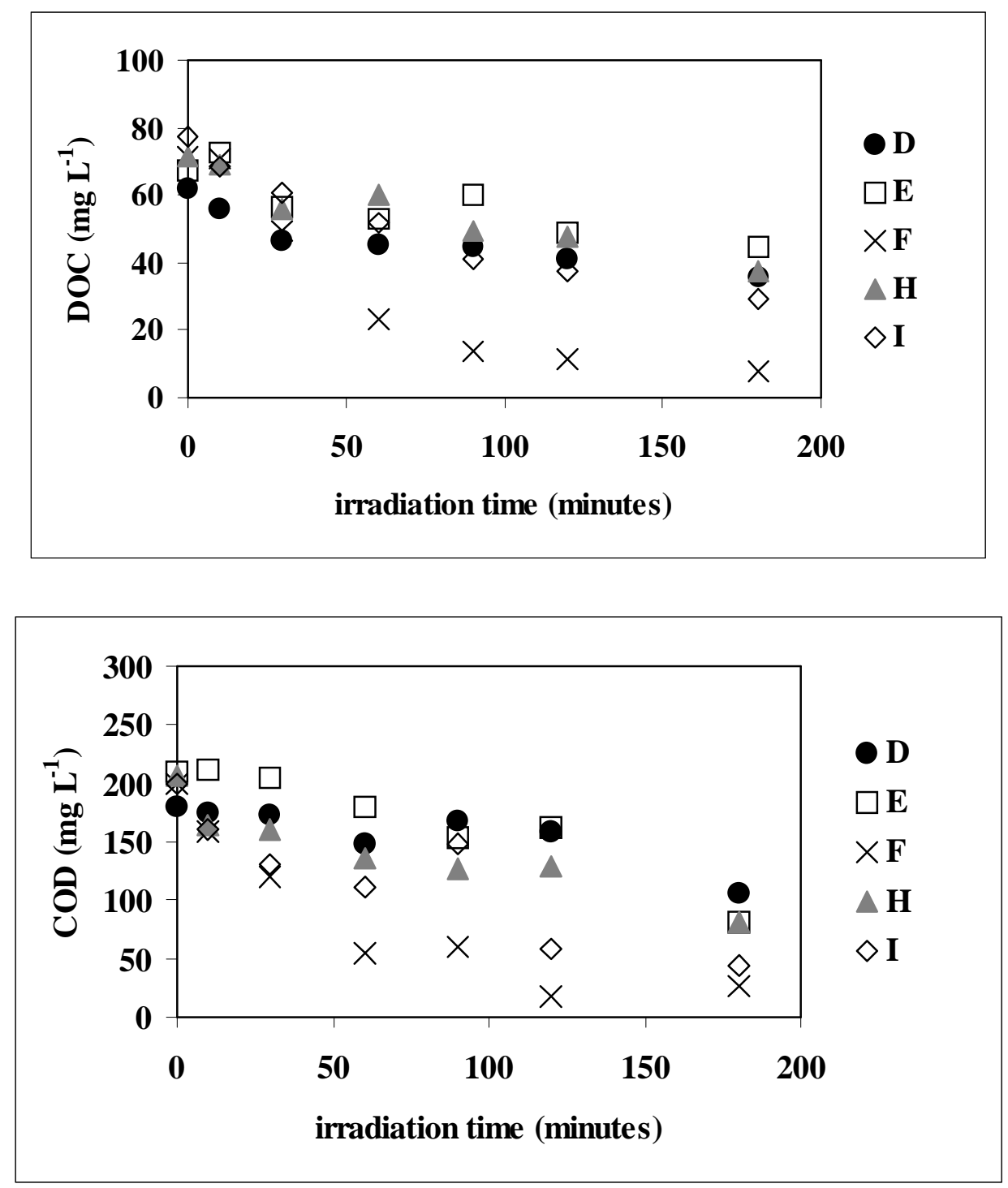

Figure 6 - Results of the photo-Fenton experiments carried out with Folicur ${ }^{\circledR} \mathrm{PM}$, at $30^{\circ} \mathrm{C}$. D $\left(\left[\mathrm{H}_{2} \mathrm{O}_{2}\right]=50 \mathrm{mmol} \mathrm{L}^{-1} ;[\mathrm{Fe}(\mathrm{II})]=2.8 \mathrm{mmol} \mathrm{L} \mathrm{m}^{-1}\right) ; \mathbf{E}\left(\left[\mathrm{H}_{2} \mathrm{O}_{2}\right]=50 \mathrm{mmol} \mathrm{L}^{-1}\right.$; $\left.[\mathrm{Fe}(\mathrm{II})]=0.5 \mathrm{mmol} \mathrm{L}{ }^{-1}\right) ; \mathbf{F}\left(\left[\mathrm{H}_{2} \mathrm{O}_{2}\right]=500 \mathrm{mmol} \mathrm{L}^{-1} ;[\mathrm{Fe}(\mathrm{II})]=0.5 \mathrm{mmol} \mathrm{L}^{-1}\right)$; $\mathbf{H}\left(\left[\mathrm{H}_{2} \mathrm{O}_{2}\right]=10 \mathrm{mmol} \mathrm{L}^{-1} ;[\mathrm{Fe}(\mathrm{II})]=0.55 \mathrm{mmol} \mathrm{L}^{-1}\right) ; \mathbf{I}\left(\left[\mathrm{H}_{2} \mathrm{O}_{2}\right]=100 \mathrm{mmol} \mathrm{L}^{-1}\right.$; $\left.[\mathrm{Fe}(\mathrm{II})]=0.55 \mathrm{mmol} \mathrm{L}^{-1}\right)$.

The results showed that increasing $\mathrm{H}_{2} \mathrm{O}_{2}$ concentration was clearly unimportant in the range

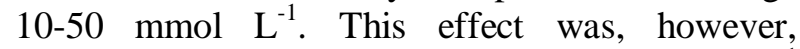
noticeable significant at $\left[\mathrm{H}_{2} \mathrm{O}_{2}\right]=500 \mathrm{mmol} \mathrm{L}^{-1}$ (experiment $\mathbf{F}$ ). In this case, a DOC removal of $68 \%$, and a COD removal of $73 \%$ were obtained in the first 60 minutes of irradiation, with final DOC and COD percent removals of about $90 \%$. A rapid variation in $\mathrm{pH}$ values (from 3.00 to a steady-state value of 2.62 after 30 minutes) was observed. On the other hand, a five-fold increase in [Fe(II)] did not seem to have a significant effect on DOC and COD-time-evolution (Fig. 6, experiments D and E), when $\mathrm{H}_{2} \mathrm{O}_{2}$ was kept at $50 \mathrm{mmol} \mathrm{L}^{-1}$. This behavior could be attributed to the photocatalytic effect. 


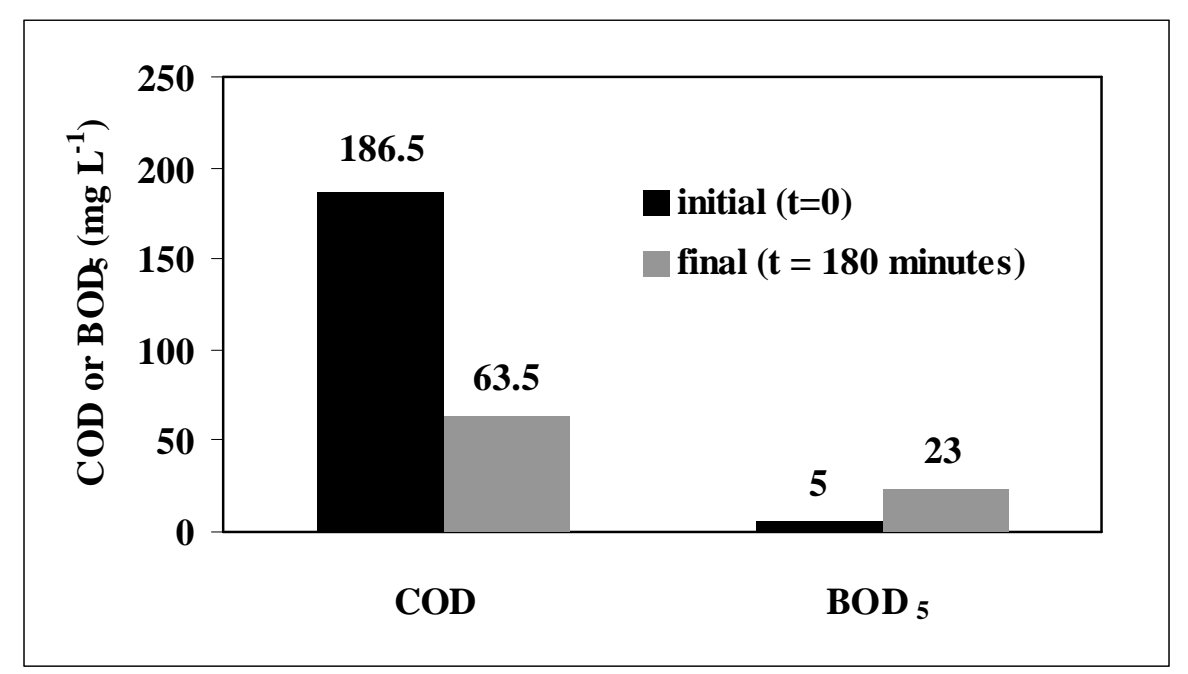

Figure 7 - Results of $\mathrm{COD}$ e $\mathrm{BOD}_{5}$ before and after the photo-Fenton experiment carried out with Folicur ${ }^{\circledR} \mathrm{PM}\left(\left[\mathrm{H}_{2} \mathrm{O}_{2}\right]=55 \mathrm{mmol} \mathrm{L}^{-1} ;[\mathrm{Fe}(\mathrm{II})]=0.55 \mathrm{mmol} \mathrm{L}^{-1} ; 30^{\circ} \mathrm{C}\right)$.
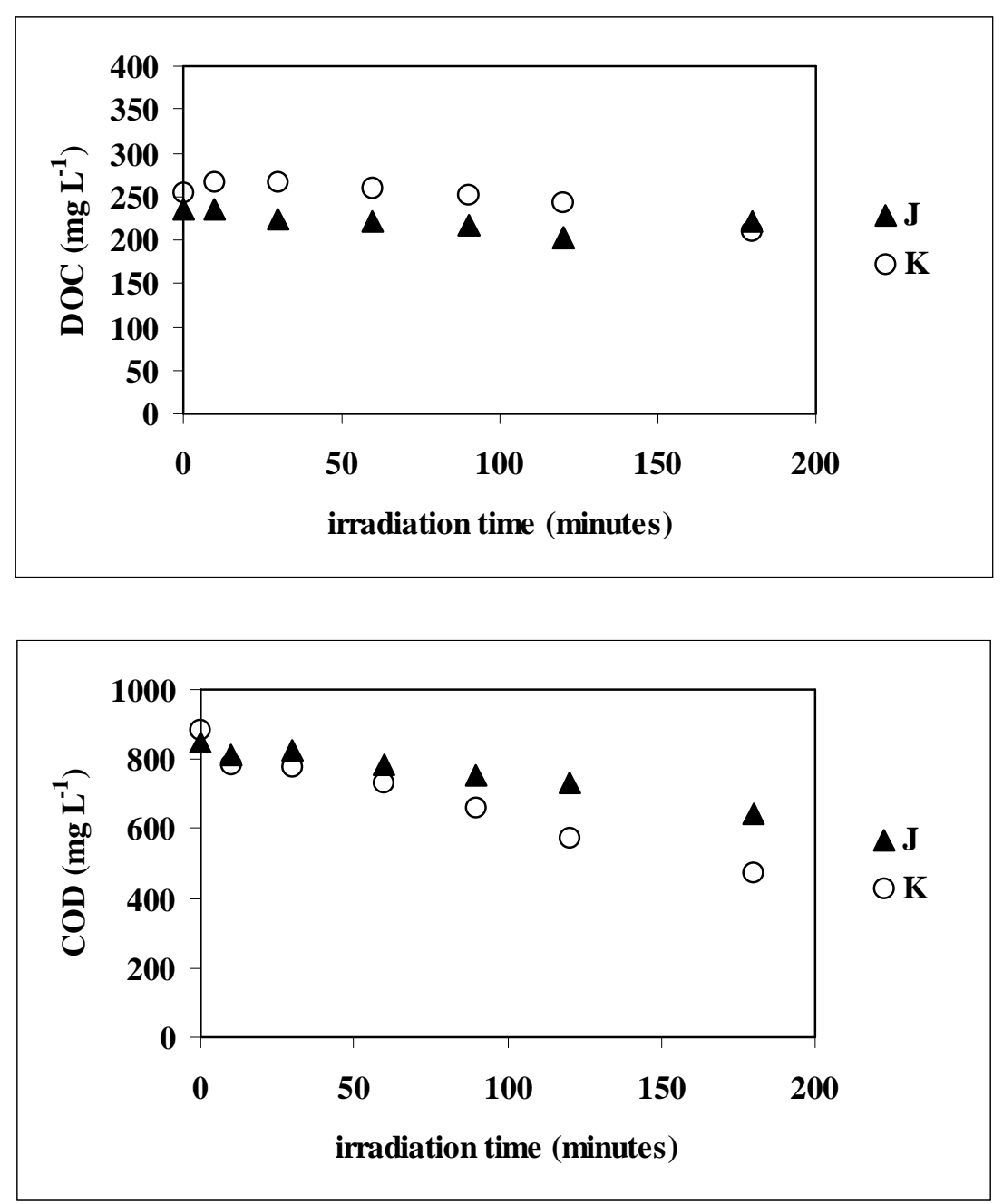

Figure 8 - Results of the photo-Fenton experiments carried out with Tamaron ${ }^{\circledR}$ BR, at $30^{\circ} \mathrm{C}$. J $([\mathrm{H} 2 \mathrm{O} 2]=55 \mathrm{mmol} \mathrm{L}-1 ;[\mathrm{Fe}(\mathrm{II})]=0.55 \mathrm{mmol} \mathrm{L}-1) ; \mathrm{K}([\mathrm{H} 2 \mathrm{O} 2]=550 \mathrm{mmol} \mathrm{L}-1$; $[\mathrm{Fe}(\mathrm{II})]=0.55 \mathrm{mmol} \mathrm{L}-1)$. 
The values of $\mathrm{BOD}_{5}$ were determined for samples taken at $\mathrm{t}=0$ and after 180 minutes in the case of a photo-Fenton experiment carried out with Folicur ${ }^{\circledR}$ $\mathrm{PM}$, at $30^{\circ} \mathrm{C}, \quad\left[\mathrm{H}_{2} \mathrm{O}_{2}\right]=55 \mathrm{mmol} \mathrm{L}^{-1}$, and $[\mathrm{Fe}(\mathrm{II})]=0.55 \mathrm{mmol} \mathrm{L}^{-1}$. Fig. 7 shows a final COD removal of $66 \%$, along with an almost five-fold increase in $\mathrm{BOD}_{5}$. The $\mathrm{BOD}_{5} / \mathrm{COD}$ ratio varied from $2.7 \%$ to $36.2 \%$. This increased biodegradability was of great importance, in view of the use of the photo-Fenton reaction as a preliminary step prior to a conventional activatedsludge biological treatment process.

The effect of the pollutant molecular structure could be analyzed by the results of the experiments carried out with the insecticide/acaricide Tamaron ${ }^{\circledR}$ BR (experiments $\mathbf{J}$ and $\mathbf{K}$, Table 2 and Fig. 8). A progressive decline in DOC and COD values with irradiation time was observed with final removals of 6 and $24 \%$, respectively (experiment $\mathbf{J}$ ), and of 18 and $46 \%$, respectively (experiment $\mathbf{K}$ ). In this case, a ten-fold increase in $\mathrm{H}_{2} \mathrm{O}_{2}$ concentration improved the performance of the photo-Fenton reaction only slightly. Fig. 8 also suggested the formation of degradation products without substantial variation in the aqueous concentration of dissolved organic carbon. Degradation products should be mainly acids, since $\mathrm{pH}$ values showed a variation in the ranges 3.03-2.47 and 3.04-2.01, for experiments $\mathbf{J}$ and $\mathbf{K}$, respectively. Therefore, the degradation of methamidophos and inert compounds seemed to occur without significant mineralization under the conditions used in the experiments.

The comparison between the results in Fig. 8 and those obtained in experiments $\mathbf{E}$ and $\mathbf{F}$ (Table 1 and Fig. 6) revealed that the increase in $\mathrm{H}_{2} \mathrm{O}_{2}$ concentration showed a more pronounced effect in tebuconazole degradation, which reinforced the recalcitrant character of methamidophos. The principal modes of reaction of $\mathrm{HO}^{\bullet}$ radicals with organic compounds included hydrogen abstraction from aliphatic carbon, electrophilic addition to double bonds and aromatic rings, and electron transfer (Bossmann et al., 1998). These seemed to be more operative in the case of tebuconazole (compare the molecular structures of each active compound, Figs. 2 and 3). The appropriate reaction conditions (temperature, $\left[\mathrm{H}_{2} \mathrm{O}_{2}\right]$ and $[\mathrm{Fe}(\mathrm{II})])$ for the photo-Fenton remediation of methamidophos-containing wastewaters should, therefore, be further investigated in view of commercial application.

\section{CONCLUSIONS}

The effectiveness of the photo-Fenton process for the remediation of agrochemical-containing wastewaters was studied. Under the experimental conditions, this process showed to be superior to other AOPs, at any $\mathrm{Fe}(\mathrm{II})$ and $\mathrm{H}_{2} \mathrm{O}_{2}$ concentrations, due to stronger light penetration and absorption up to $410 \mathrm{~nm}$ under homogeneous photocatalysis. This behavior makes the commercial use of solar-driven photo-Fenton processes environmentally attractive (Teixeira et al., 2003), lowering electrical energy costs. In the case of the contaminant tebuconazole, the increase in the $\mathrm{BOD}_{5} / \mathrm{COD}$ ratio suggested the use of the photo-Fenton reaction as a preliminary step prior to conventional biological treatment processes.

\section{ACKNOWLEDGEMENTS}

The authors would like to thank FAPESP and $\mathrm{CNPq}$ for financial support. Sincere thanks are also directed to Bayer CropScience and to Prof. Dr. Gilberto Batista (LARP/ESALQ-USP), for the samples of Tamaron ${ }^{\circledR}$ BR and Folicur ${ }^{\circledR}$ PM.

\section{RESUMO}

Neste trabalho, estuda-se a degradação fotoquímica de defensivos agrícolas presentes em efluentes aquosos, por meio de processos oxidativos avançados (POAs). Tais processos são baseados na ação do radical hidroxila $\left(\mathrm{HO}^{\bullet}\right)$, oxidante poderoso e não seletivo. Em particular, o processo foto-Fenton é avaliado quanto à redução da demanda química de oxigênio (DQO) e do teor de carbono orgânico dissolvido (COD), e ao aumento de biodegradabilidade dos efluentes. Os resultados abrem perspectivas para emprego de irradiação solar e aplicação em escala comercial a baixo custo.

\section{REFERENCES}

Acero, J. L.; Benitez, F. J.; Gonzalez, M. and Benitez, R. (2002), Kinetics of fenuron decomposition by single-chemical oxidants and combined systems. Ind. Eng. Chem. Res., 41, 4225-4232. 
Bossmann, S. H.; Oliveros, E.; Göb, S.; Siegwart, S.; Dahlen, E. P.; Payawan, L.; Straub, M.; Wörner, M. and Braun, A. M. (1998), New evidence against hydroxyl radicals as reactive intermediates in the thermal and photochemically enhanced Fenton reactions. J. Phys. Chem. A, 102, 5542-5550.

Burrows, H. D.; Canle, L. M.; Santaballa, J. A. and Steenken, S. (2002), Reaction pathways and mechanisms of photodegradation of pesticides. $J$. Photochem. Photobiol. B - Biol., 67, 71-108.

Chiron, S.; Fernandez-Alba, A.; Rodriguez, A. and Garcia-Calvo, E. (1999), Pesticide chemical oxidation: state-of-the-art. Water Res., 34, 366-377.

Esplugas, S.; Giménez, J.; Contreras, S.; Pascual, E. and Rodríguez, M. (2002), Comparison of different advanced oxidation processes for phenol degradation. Water Res., 36, 1034-1042.

Lipczynska-Kochany, E. (1991), Degradation of aqueous nitrophenols and nitrobenzenes by means of the Fenton reaction. Chemosphere, 22, 529-536.

Malato, S.; Blanco, J.; Richter, C. and Maldonado, M. I. (2000), Optimization of pre-industrial solar photocatalytic mineralization of commercial pesticides - application to pesticide container recycling. Appl. Catal. B - Environ., 25, 31-38.

Teixeira, A. C. S. C.; Guardani, R. and Nascimento, C. A. O. (2003), Solar photochemical degradation of aminosilicones contained in liquid effluents. Process studies and neural network modeling. Ind. Eng. Chem. Res., 42, 5751-5761.

Teixeira, A. C. S. C.; Guardani, R. and Nascimento, C. A. O. (2004), Photo-Fenton remediation of wastewaters containing silicones: experimental study and neural network modeling. Chem. Eng. Technol., 27, 800-810.

Tundisi, J. G. (2003), Água no Século XXI: Enfrentando a Escassez. Instituto Internacional de Ecologia, RiMa Editora, São Carlos. 